\title{
Uji Aktivitas Antioksidan dan Profil Fitokimia Ekstrak Kayu Beta-beta (Lunasia amara Blanco.)
}

\author{
(Antioxidant Activity and Phytochemical Profile of Beta-beta (Lunasia amara Blanco) Wood \\ Extract) \\ Hasnaeni $^{{ }^{*}}$, Aminah ${ }^{2}$ \\ ${ }^{1}$ Laboratorium Farmakognosi Fitokimia, Fakultas Farmasi, Universitas Muslim Indonesia, Makassar \\ ${ }^{2}$ Laboratorium Kimia, Fakultas Farmasi, Universitas Muslim Indonesia, Makassar
}

\section{Article Info:}

Received: 06 March 2019

in revised form: 20 March 2019

Accepted: 31 March 2019

Available Online: 31 March 2019

\section{Keywords:}

Beta-beta,

Lunasia amara,

Antioxidant,

DPPH,

Phytochemical

Corresponding Author:

Hasnaeni

Laboratorium Farmakognosi

Fitokimia

Fakultas Farmasi

Universitas Muslim Indonesia

Makassar, 90245

Email : hasnaeni.hasnaeni@umi.ac.id

\begin{abstract}
Beta-beta wood (Lunasia amara Blanco) is one of the Rutaceae plants. It has been used traditionally in Indonesia, both in the form of a single extract or in a mixture of several herbs, for the treatment of swollen feet, skin diseases and inflammation or irritation of the eyes. This study aims to examine the antioxidant activity and the phytochemical profile of beta-beta wood extract. The research methods include plant extraction by maceration, testing of antioxidant activity by 2,2-diphenyl-1-picrylhydrazyl (DPPH) method and phytochemical profiling with specific chemical reagents. The results showed that beta-beta wood extract (Lunasia amara Blanco) has antioxidant activity with IC 50 was $69.46 \mu \mathrm{g} / \mathrm{ml}(0.069 \mathrm{mg} / \mathrm{ml})$ and it contained steroid, phenolic, saponin, alkaloid and coumarin compounds.
\end{abstract}

Copyright (C) 2019 JFG-UNTAD

This open access article is distributed under a Creative Commons Attribution (CC-BY-NC-SA) 4.0 International license.

How to cite (APA 6th Style):

Hasnaeni., Aminah. (2019). Uji Aktivitas Antioksidan dan Profil Fitokimia Ekstrak Kayu Beta-beta (Lunasia amara Blanco). Jurnal Farmasi Galenika : Galenika Journal of Pharmacy, 5(1), 101 - 107. doi:10.22487/j24428744. 2019.v5.i1.12404 


\begin{abstract}
ABSTRAK
Kayu beta-beta (Lunasia amara Blanco) merupakan salah satu tanamansuku Rutaceae.Secara tradisional tanaman ini telah digunakan di Indonesia baik dalambentuk ekstrak tunggal atau dalam campuran beberapa herbal untuk pengobatankaki bengkak, penyakit kulit dan radang atau iritasi pada mata. Pada penelitian ini telah dilakukan uji aktivitas antioksidan dan pemeriksaan profil fitokimia ekstrak kayu beta-beta (Lunasia amara). Metode penelitian meliputi ekstraksi tumbuhan secara maserasi, pengujian aktivitas antioksidan dengan metode 2,2-diphenyl-1-picrylhydrazyl (DPPH) dan profil fitokimia dengan pereaksi kimia yang spesifik. Hasil penelitian diperoleh adanya aktivitas antioksidan dari ekstrak kayu beta-beta (Lunasia amara) dengan IC $_{50}$ sebesar 69,46 $\mu \mathrm{g} / \mathrm{ml}(0,069 \mathrm{mg} / \mathrm{ml})$ dan adanya kandungan senyawa steroid, fenolik, saponin, alkaloid dan kumarin.
\end{abstract}

Kata Kunci : Kayu beta-beta, Lunasia amara, antioksidan, 2,2-Diphenyl-1-picrylhydrazyl (DPPH) , fitokimia

\section{PENDAHULUAN}

Pengobatan dari herbal telah banyak menarik perhatian dan berkembang sangat cepat. Tanaman yang merupakan bahan baku obat tradisonal tersebut tersebar hampir di seluruh wilayah Indonesia. Penggunaan tanaman sebagai sumber alami senyawa obat seperti yang termasuk dalam kayu beta-beta (Lunasia amara Blanco) famili rutaceae telah dilakukan sejak ribuan tahun. Manusia menggunakan tanaman dan produk tanaman itu untuk mengatasi berbagai gangguan fisik dan mental.Namun sejalan dengan penggunaan obat herbal yang meningkat, ketersediaan bahan baku yang mengandung senyawa aktif masih sangat terbatas.Demikian pula kenyataan yang sering dijumpai dalam penggunaan obat terutama obat sintetik yaitu efektivitas obat yang terbatas dalam menurunkan perkembangan penyakit, efek samping yang serius dan efek toksik yang tinggidan biaya yang tinggi (Cai et al., 2005).

Penelitian ini dilakukan sebagai upaya eksplorasi bahan baku obat bahan alam yaitu kayu beta-beta (Lunasia amara Blanco). Kayu beta-beta telah banyak dikenal dikalangan masyarakat terutama sebagai obat aprodisia. Khasiat kayu beta-beta tidak hanya terbatas sebagai aprodisia namun dapat juga sebagai antiinflamasi sebagaimana yang dilakukan pada penelitian sebelumnya yaitu adanya efek antiinflamasi terhadap mencit model rheumatoid arthritis (RA)(Kumar et al., 2006).

Berdasarkan pada pendekatan kemotaksonomi diketahui beberapa tanaman dari suku rutaceae seperti Murraya paniculata, Clausena pentaphylla, Feronia limonia (L.) Swingle dan Chloroxylon sweitenia mengandung senyawa kumarin yang mempunyai aktivitas sebagai antiinflamasi (Wambugu et al., 2011; Choudhary et al., 2002; Kumar et al., 2006).

Saat ini banyak penyakit-penyakit degeneratif seperti kanker, jantung, arthritis, diabetes, liver dan sebagainya. RA adalah termasuk salah satu penyakit degeneratif yang banyak terjadi di masyarakat. Penyakit degeneratif ini disebabkan karena antioksidan yang ada di dalam tubuh tidak mampu menetralisir peningkatan konsentrasi radikal bebas.Radikal bebas seperti oksigen reaktif, spesies nitrogen dapat merusak komponen artikular pada sendi yang ditandai dengan inflamasi radang sendi. Radikal bebas seperti radikal hidroksil dapat menurunkan proteoglikan dalam matriks artikular, Jaringan inhibitor metaloprotein di non aktifkan oleh radikal peroksinitrat dengan menghancurkan jaringan tulang rawan. RA akan berkembang selama tidak ada penghambatan terhadap sitokin, protease, antioksidan dan faktor angiogenik (Kumar et al., 2006).

Dalam penelitian ini dilakukan uji aktivitas antioksidan dan penelusuran profil fitokimia ekstrak kayu beta-beta untuk lebih menambah data ilmiah dari kayu beta-beta. Sehingga penggunaan kayu betabeta sebagai bahan baku obat lebih dapat dipertanggungjawabkan.

\section{METODE PENELITIAN}

\section{Alat dan Bahan}

Alat yang digunakan adalah bejana maserasi, batu didih, corongpisah, rotavapor (Heidolph, Germany), alat gelas. Spektrofotometer UV-Vis Varian Cary, timbangan analitis (Sartorius), labu ukur, oven (Memmert, Germany), botol coklat, stopwatch, timbangan milligram, beaker glass, pipet volume, pipet ukur 
Bahan yang digunakan adalah tanaman kayu betabeta (Lunasia amara Blanco) yang diambil dari daerah Siawung, Kabupaten Barru, Sulawesi Selatan, etanol, air suling,Meyer, Liebermann-Burchard (Merck), $\mathrm{H}_{2} \mathrm{SO}_{4} 2 \mathrm{~N}$ (Merck), $\mathrm{HCl}($ Merck), aquadest, butir bubuk magnesium, anhidrida asetat, $\mathrm{FeCl}_{3} 1 \%$ (Merck), kertas saring, plat KLT, $\mathrm{NaOH} \mathrm{1 \% ,} \mathrm{dan}$ DPPH. Bahan kimia yang digunakan adalah berkualitas Pro Analisis.

\section{Metode Penelitian}

\section{Pengolahan sampel}

Sampel kayu beta beta dibersihkan dan dikeringkan pada udara terbuka sampai diperoleh bahan dengan kadar air $\pm 10 \%$. Setelah kering sampel dibuat serbuk dengan ukuran 60 mesh.

\section{Ekstraksi sampel}

Serbuk kayu beta-beta ukuran 60 mesh sebanyak 1000 g diekstraksi secara maserasi pada suhu kamar dengan etanol $70 \%$ selama 72 jam. Proses maserasi di ulang 3 kali dengan pelarut yang sama. Ekstrak etanol dikumpulkan dan diuapkan dengan rotary evaporator vakum (penguap putar) sehingga diperoleh ekstrak etanol kental. Ekstrak kental tersebut kemudiandikeringkan dengan cawan porselin di atas penangas air dan ditimbang sehingga dapatdiperoleh rendemen ekstrak. Ekstrak yang diperoleh di uji aktivitas antioksidannya dan profil fitokimianya.

\section{Uji aktivitas antioksidan dengan pengukuran absorbansi peredaman radikal bebas DPPH}

Ekstrak etanol kayu beta-beta sebagai larutan uji dilarutkan dengan metanol dan diencerkan secara seri sehingga diperoleh konsentrasi sampel uji: 10 , 20, 40, 60, dan $80 \mu \mathrm{g} / \mathrm{mL}$. Sebanyak $4 \mathrm{ml}$ sampel uji ditambahkan $1 \mathrm{ml}$ larutan pereaksi DPPH 0,004\%. Larutan uji dan kontrol didiamkan (inkubasi) pada suhu kamar selama 30 menit di tempat gelap. Setelah inkubasi kemudian dibaca serapan aktivitasnya pada panjanggelombang maksimum 394 nm. Blangko yang digunakan adalah metanol dan Vitamin C sebagai kontrol positif (Al-Abd et al., 2015).

\section{Uji profil fitokimia}

Profil fitokimia ekstrak dilakukan dengan menggunakan beberapa pereaksi kimia. Pengujian profil fitokimia yang meliputi uji steroid menggunakan pereaksi asam asetat anhidrat + asam sulfat + kloroform, uji fenolik menggunakan $\mathrm{FeCl}_{3}$, uji saponin menggunakan air panas $10 \mathrm{ml}$, uji alkaloid menggunakan pereaksi Mayer, Dragendorf dan Bouchardad dan uji kumarin menggunakan plat KLT dengan $\mathrm{KOH} 10 \%$ dan $\mathrm{NaOH} 1 \%$ (Ferdinal at al., 2015).

\section{Analisa data}

Aktivitas antioksidan diekspresikan sebagai jumlah antioksidan yang dibutuhkan untuk menurunkan 50 persen radikal $\mathrm{DPPH}\left(\mathrm{IC}_{50}\right)$. Nilai $\mathrm{IC}_{50}$ masing-masing sampel ditentukan secara grafik dengan memplotkan persen penangkapan radikal bebas dengan log konsentrasi. Dari grafik tersebut nilai IC $_{50}$ ditentukan melalui regresi linier.

\% penangkapan radikal bebas dihitung dengan rumus:

$$
\frac{\text { Abs .kontrol - Abs.sampel }}{\text { Abs.Kontrol }} \times 100 \%
$$

\section{HASIL DAN PEMBAHASAN}

\section{Hasil Ekstraksi}

Ekstraksi sebanyak 1000 gram serbuk kayu beta-beta dilakukan dengan metode maserasi menggunakan pelarut etanol 70\% dengan 3 kali ekstraksi diperoleh ekstrak etanol kering yang berwarna coklat tua dengan rendemen $1,545 \%$.

\section{Pengukuran aktivitas antioksidan dengan metode DPPH}

Pengujian aktivitas antioksidan dilakukan terhadap ekstrak etanol kayu beta-beta. Dibuat larutan stok dengan konsentrasi 10,3 mg/ml kemudian diukur serapan absorbansi pada panjang gelombang $394 \mathrm{~nm}$. Absorbansi yang diperoleh dihitung menjadi persen penangkapan radikal bebas. 
Tabel 1. Hasil pengukuran absorbansi dan $\mathrm{IC}_{50}$ etanol kayu beta-beta (Lunasia amara Blanco)

\begin{tabular}{|c|c|c|c|c|c|c|c|c|}
\hline \multirow{2}{*}{$\begin{array}{c}\text { Konsentrasi } \\
\qquad(\mu \mathrm{g} / \mathrm{ml})\end{array}$} & \multicolumn{3}{|c|}{ Replikasi } & \multicolumn{3}{|c|}{$\begin{array}{c}\% \text { penangkapan radikal } \\
\text { bebas }\end{array}$} & \multirow{2}{*}{$\begin{array}{c}\text { Rata-rata \% } \\
\text { Penangkapan } \\
\text { radikal bebas }\end{array}$} & \multirow{2}{*}{$\mathrm{IC}_{50}$} \\
\hline & I & II & III & I & II & III & & \\
\hline 20.6 & 0.617 & 0.611 & 0.620 & 29.81 & 30.49 & 29.47 & 29.92 & \\
\hline 41.2 & 0.541 & 0.539 & 0.538 & 38.45 & 38.68 & 38.79 & 38.64 & \\
\hline 82.4 & 0.391 & 0.390 & 0.398 & 55.52 & 55.63 & 54.72 & 55.29 & 69.46 \\
\hline 123.6 & 0.240 & 0.241 & 0.246 & 72.70 & 72.58 & 72.01 & 72.43 & \\
\hline 164.8 & 0.098 & 0.101 & 0.095 & 88.85 & 88.51 & 89.19 & 88.85 & \\
\hline
\end{tabular}

Aktivitas penangkapan radikal bebas (aktivitas antioksidan) ditunjukkan dalam grafik sebagai berikut :

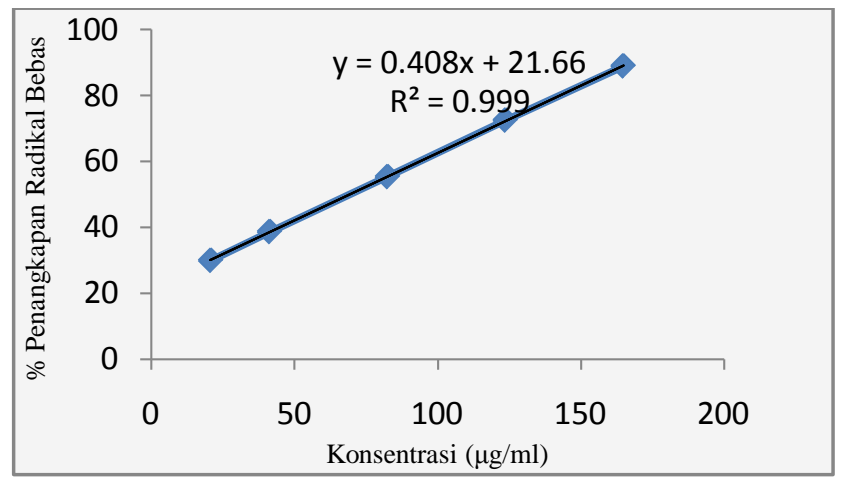

Gambar 1. Aktivitas antioksidan ekstrak etanol kayu betabeta (Lunasia amara Blanco)

Dari hasil perhitungan aktivitas antioksidan diketahui bahwa ekstrak kayu beta-beta memiliki aktivitas antioksidan dengan $\mathrm{IC}_{50}$ sebesar $69,46 \mu \mathrm{g} / \mathrm{ml}(0,069$ $\mathrm{mg} / \mathrm{ml}$ ), sedangkan vitamin $\mathrm{C}$ sebagai kontrol positif diperoleh $\mathrm{IC}_{50}$ sebesar $2,34 \mu \mathrm{g} / \mathrm{mL}(0,002 \mathrm{mg} / \mathrm{mL})$. Hasil ini lebih baik bila dibandingkan dengan hasil penelitian antioksidan terhadap $L$. amara yang dilakukan oleh Totaan, et al (2018). Mekanisme aksi antara antioksidan dan DPPH tergantung pada konformasi struktur antioksidan. Pada umumnya aktivitas antioksidan meningkat dengan peningkatan jumlah gugus hidroksil (-OH) atau gugus yang dapat mendonasikan $\mathrm{H}$ seperti $-\mathrm{NH}$ atau $-\mathrm{SH}$ dalam struktur molekul suatu senyawa (Son et al., 2002).
Kayu beta-beta sebagai salah satu tanaman yang termasuk famili rutaceae diketahui mengandung senyawa seperti skopoletin yang termasuk dalam golongan senyawa kumarin (Hegnauer, 1973) dimana struktur molekul dapat diperlihatkan sebagai berikut :<smiles>O=Cc1cc2ccc(=O)oc2cc1O</smiles>

7-hydroxy-6-methoxycoumarin (skopoletin)

Sifat antioksidan kayu beta-beta kemungkinan disebabkan oleh adanya gugus hidroksil $(-\mathrm{OH})$ yang dimiliki oleh senyawa tersebut yang terdapat dalam kayu beta-beta. Jika dibandingkan dengan aktivitas antioksidan standar yaitu vitamin C, maka aktivitas antioksidan ekstrak kayu beta-beta jauh lebih rendah dari vitamin C. Vitamin C memiliki kemapuan mendonorkan ion $\mathrm{H}\left(\mathrm{H}^{+}\right)$dan radikal $\mathrm{H}\left(\mathrm{H}^{\circ}\right)$ dan mampu mendonorkan elektronnya $(e)$ pada radikal DPPH.

Radikal bebas disebut sebagai reactive oxigen species (ROS) adalah suatu istilah yang mencakup seluruh molekul yang memiliki reaktivitas tinggi, mengandung oksigen, termasuk radikal bebas. Spesies oksigen reaktif meliputi radikal bebas anion superoksida $\left(\mathrm{O}^{-*}\right)$, radikal perhidroksil $\left(\mathrm{HO}_{2}{ }^{\circ}\right)$, radikal hidroksil $\left({ }^{\circ} \mathrm{OH}\right)$, radikal nitrit oksida (NO'), radikal hipoklorit $\left(\mathrm{HOCl}^{*}\right)$ dan spesies lain seperti 
hidrogen peroksida $\left(\mathrm{H}_{2} \mathrm{O}_{2}\right)$ dan singlet oksigen $\left({ }^{1} \mathrm{O}_{2}\right)$, dan peroksinitrat (ONOO') (Vajragupta et al., 2004).

Radikal bebas adalah molekul yang pada orbit terluarnya mempunyai satu atau lebih elektron tidak berpasangan, sifatnya sangat labil dan sangat reaktif sehingga dapat menimbulkan kerusakan pada komponen sel seperti DNA, lipid, protein dan karbohidrat. Kerusakan tersebut dapat pula menimbulkan berbagai kelainan biologis seperti arterosklorosis, kanker, diabetes dan penyakit degeneratif lainnya (Chen et al., 1996). Radikal bebas dapat berasal dari dalam tubuh maupun dari lingkungan. Manusia setiap detiknya menghasilkan radikal bebas. Radikal bebas dapat dihasilkan pada proses respirasi, proses pencernaan dan proses metabolisme. Peningkatan radikal bebas dapat pula dipacu oleh stres atau olahraga yang berlebihan. Faktor lingkungan dapat juga meningkatkan radikal bebas seperti polusi udara, radiasi matahari (ultraviolet), zat kimia, asap rokok, asap kendaraan bermotor, dan masih banyak lagi yang lainnya. Pada awalnya radikal bebas dianggap tidak merugikan kesehatan manusia. Tetapi berdasarkan penelitian ilmiah, radikal bebas dapat merusak sel pada manusia, yang akan merambat pada kerusakan jaringan tubuh (Harmanto, 2007).Radikal bebas seperti oksigen reaktif, spesies nitrogen dapat merusak komponen artikular pada sendi yang ditandai dengan inflamasi radang sendi. Radikal bebas seperti radikal hidroksil juga dapat menurunkan proteoglikan dalam matriks artikular, Jaringan inhibitor metaloprotein di non aktifkan oleh radikal peroksinitrat dengan menghancurkan jaringan tulang rawan (Kumar et al., 2006).

Antioksidan adalah molekul yang dapat menetralkan radikal bebas dengan mendonorkan elektronnya untuk mengakhiri keadaan tidak berpasangan dari radikal. Antioksidan dapat menurunkan kerusakan oksidatif secara langsung melalui reaksi dengan radikal bebas atau secara tidak langsung dengan menghambat aktivitas atau ekspresi enzim yang menghasilkan radikal bebas atau dengan meningkatkan aktivitas atau ekspresi enzim antioksidan seluler (Lu et al., 2010).

Peranan antioksidan sangat penting dalam menetralkan dan menghancurkan radikal bebas yang dapat menyebabkan kerusakan sel dan juga merusak biomolekul, seperti DNA, protein dan lipoprotein di dalam tubuh yang akhirnya dapat memicu terjadinya penyakit degeneratif, seperti kanker, jantung, artritis, katarak, diabetes dan hati. Untuk menghindari hal tersebut, dibutuhkan antioksidan tambahan dari luar atau antioksidan eksogen, seperti vitamin $\mathrm{E}$ dan vitamin C maupun berbagai jenis sayuran dan buahbuahan.Antioksidan alami mampu melindungi tubuh terhadap kerusakan yang disebabkan oleh spesies oksigen reaktif, menghambat terjadinya penyakit degeneratif dan mampu menghambat peroksidase lipid pada makanan. Minat untuk mendapatkan antioksidan alami semakin meningkat.

Merode yang digunakan untuk uji aktivitas antioksidan banyak dilakukan dengan metode DPPH, karena metode ini memberikan informasi reaktivitas senyawa yang diuji dengan suatu radikal stabil. Penggunaan senyawa antioksidan semakin meningkat sejalan dengan pemahaman dan kesadasaran manusia mengenai pentingnya antioksidan dalam menghambat penyakit degeneratif seperti penyakit jantung, arteriosklerosis, kanker serta gejala penuaan.

\section{Skrining profil fitokimia}

Tabel 2. Hasil pemeriksaan profil fitokimia pada ekstrak etanol kayu beta beta (Lunasia amara Blanco)

\begin{tabular}{ccc}
\hline $\begin{array}{c}\text { Pemeriksaan } \\
\text { golongan }\end{array}$ & Pereaksi & Hasil \\
\hline Steroid & $\begin{array}{c}\text { Asamasetatanh } \\
\text { idrat }+\mathrm{H}_{2} \mathrm{SO}_{4} \\
+\mathrm{CHCl}_{3}\end{array}$ & $\begin{array}{c}+ \\
\text { (Cincin merah) }\end{array}$ \\
Fenolik & $\mathrm{FeCl}_{3}$ & + \\
Saponin & $\begin{array}{c}\text { Air panas } 10 \\
\text { ml, dikocok } \\
\text { (Ungu tua) } \\
\text { Alkaloid }\end{array}$ & $\begin{array}{c}+ \\
\text { (Busa stabil) } \\
+\end{array}$ \\
& $\begin{array}{c}\text { Dragendorf } \\
\text { (Endapan putih) } \\
+\end{array}$ & $\begin{array}{c}+ \\
\text { (Endapan coklat) } \\
+\end{array}$ \\
& $\begin{array}{c}\text { Bouchardad } \\
\text { KOH 10\% }\end{array}$ & $\begin{array}{c}\text { (Endapan coklat) } \\
+\end{array}$ \\
& $\begin{array}{c}\text { pada lampu } \\
\text { UV }\end{array}$ & (Flouresensi biru) \\
\hline
\end{tabular}

Hasil pemeriksaan profil fitokimia ekstrak atanol kayu beta-beta menunjukkan adanya golongan, steroid, fenolik, saponin, alkaloid dan kumarin. Pemeriksaan profil fitokimia ini dimaksudkan untuk memberikan gambaran atau untuk mengetahui kelompok senyawa yang terkandung secara umum dalam kayu beta-beta (Lunasia amara Blanco). 
Berdasarkan pendekatan kemotaksonomi dari tumbuhan famili rutaceae diketahui kandungan senyawa bioaktif antara lain golongan alkaloid, yakni lunakridina, lunakrina, lunasina dan lunanin; kalsium oksalat, asam formiat, steroid dan glukosida (Goodwin dan Horning, 1959; Hegnauer, 1969; Katno dan Haryanti, 2009; Zubair et al., 2010).

\section{KESIMPULAN}

Dari hasil penelitian, dapat disimpulkan ekstrak kayu beta-beta (Lunasia amara Blanco) memiliki aktivitas antioksidandengan $\mathrm{IC}_{50}$ sebesar 69,46 $\mu \mathrm{g} / \mathrm{ml}(0,069$ $\mathrm{mg} / \mathrm{ml}$ dan mengandung senyawa golongan steroid, fenolik, saponin, alkaloid dan kumarin.

\section{UCAPAN TERIMA KASIH}

Lembaga Penelitian dan Pengembangan Sumber Daya (LP2S) Universitas Muslim Indonesia melalui dana hibah Dosen Pemula internal UMI 2016.

\section{DAFTAR PUSTAKA}

Al-Abd, N. M., Mohamed Nor, Z., Mansor, M., Azhar, F., Hasan, M. S., \& Kassim, M. (2015). Antioxidant, antibacterial activity, and phytochemical characterization of Melaleuca cajuputi extract. BMC complementary and alternative medicine, 15 , 385.

Backer, C.A., Van den Brink, Jr.R.C.B. (1969). Flora of Java, Vol. 2, 99, N.V.P. Noordhoff, Groningen.

Cai, X., Zhou, H., Wong, Y.F., Xie, Y., Liu, Z.Q., Jiang, Z.H, et al. (2005). Suppressive effect of QFGJS, a preparation from anti-arthritic herbal formula, on rat experimental adjuvant-induced arthritis. Biochem. Biophys, Res Commun. 337(2), 586-596

Chen, HM., Koji, M., Fumio, Y., Kiyoshi N. (1996). Antioxidant activity of designed peptides based on the antioxidative peptide isolated from digest of a soybean protein, J. Agric. Food Chem. 44: 2619-2623.

Choudhary, M. I., Azizuddin, Khalid, A., Sultani, S. Z., dan Atta-ur-Rahman. (2002). A new coumarin from Murraya paniculata. Planta Med., 68(1), 81-83.
Goodwin, S., Horning, E. C. (1959). Alkaloids of Lunasia amara Blanco. Structure of lunacrine. J. Am. Chem. Soc., 81(8), 1908-1912.

Harmanto, N. (2002). Sehat dengan Ramuan Tradisional Mahkota dewa, Cetakan empat, Tangerang, PT. Agromedia Pustaka, Jakarta.

Hegnauer, R. (1969). Chemotaxonomi der Planzen, edisi V. Birkkhauser Verlag. Basel and Stuttgart.

Iaroshenko, V. O., Erben, F., Mkrtchyan, S., Hakobyan, A., Vilches-Herrera, M., Dudkin, S., et al. (2011). 4-Chloro-3-(trifluoroacetyl)and 4-chloro-3-(methoxalyl)coumarins as novel and efficient building blocks for the regioselective synthesis of 3,4-fused coumarins. Tetrahedron, 67(41), 7946-7955.

Katno, K., dan Haryanti, S. (2009). Efek afrodisiaka ekstrak kayu sanrego (Lunasia amara Blanco) terhadap tikus putih jantan. J. Tumbuh. Obat Indonesia., 2(1).

Kumar, K., Ganesh, M., Baskar, S., Srinivasan, K., Kanagasabai, R., Sambathkumar, R., et al. (2006). Evaluation of Anti-inflammatory activity and toxicity studies of Chloroxylonsweitenia in Rats. Anc. Sci. Life, 25(3-4), 33-43.

Lu, J.M., Lina, P.H., Yaoa, Q.,dan Chena, C. (2010). Chemical and molecular mechanisms of antioxidants: Experimental approaches and model systems. J Cell Mol Med. 14(4): 84060.

Luthfi, M. J., Mat Noor, M. (2009). Effects of aqueous extract Lunasia amara blanco on sperm quality, fertility and sexual behaviour of male rats. Sains Malays., 38(5), 793-797.

Profil Desa Siawung Kabupaten Barru. (2013). Dinas Pertanian dan Tanaman Pangan kabupaten Barru.

Rohdiana, D. (2001). Aktivitas Daya Tangkap Radikal Polifenol Dalam Daun Teh, Majalah Jurnal Indonesia 12, (1), 53-58.

Son, S. Lewis, B.A. (2002). Free radical scavenging and antioksidative activity of caffeic acid amide and ester analogues: structure activity 
relationship. J. Agric. Food. Chem., 50, 468472.

Zubair, M.S., Subehan. (2010). Molecular Docking of Lunacridine from Lunasia amara to DNA : Its inhibition and interaction study correlated with the cytotoxic activity on P388 Murine Leukimia Cells. Indonesian Journal of cancer Chemoprevention, 1(2), 108-117.

Vajragupta, O., Boonchoong, P., Berliner, L.J. (2004). Manganese complexes of curcumin analogues: evaluation of hydroxyl radical scavenging ability, superoxide dismutase activity and stability towards hydrolysis. Free Radic Res., 38, 303-314.

V Totaan, I.D., D Clavic, Z., C Nicholas, M.A., V Totaan, E. (2018). Antioxidant, Antibacterial and Anti-Calstogenius Activities of Lunasia amara, Blanco Leaf extract, I. J of Advanced Sci and Tech. Res., 8(1).

Wambugu, S. N., Mathiu, P. M., Gakuya, D. W., Kanui, T. I., Kabasa, J. D., dan Kiama, S. G. (2011). Medicinal plants used in the management of chronic joint pains in Machakos and Makueni counties, Kenya. J. Ethnopharmacol., 137(2), 945-955. 